\title{
Diagnostický potenciál synoviálnej tekutiny
}

\author{
(Pôvodná práca - klinická štúdia) \\ Diagnostic Potential of the Synovial Fluid
}

(Original Article - Clinical Study)

Schwartzová V.', Kluknavská J.', Birková A. ${ }^{2}$, Rabajdová M. ${ }^{2}$

II. stomatologická klinika LF UPJŠ, Košice,

2Ústav lekárskej a klinickej biochémie LF UPJŠ, Košice

\section{SÚHRN}

Úvod: Biochemické zmeny sprevádzajúce intrakapsulárne patologické procesy predstavujú potenciálny zdroj informácií využitelný na diagnostiku, diferenciálnu diagnostiku či monitorovanie ochorení temporomandibulárneho kíbu. Miniinvazívne zásahy do integrity temporomandibulárneho kíbu so sprístupnením synoviálnej tekutiny sa v stomatologickej praxi realizujú za účelom drenáže, prípadne terapeutických laváži a nie za účelom stanovenia akéhokol'vek biochemického parametra. Okrem invazivity punkcie temporomandibulárneho kíbu využitel'nost' synoviálnej tekutiny z tejto lokality na diagnostiku komplikuje jej nízky objem. Ciel'om práce je zhrnút aktuálne poznatky o histológii, fyziológii a patofyziológii temporomandibulárneho kíbu, vyhodnotit možnosti vyšetrenia synoviálnej tekutiny a otestovat' diagnostický potenciál tejto tekutiny pomocou vysoko citlivej fluorescenčnej fingerprintovej analýzy.

Klíčová slova: temporomandibulárny kíb - synoviálna tekutina - osteoartróza - fluorescencia

\section{SUMMARY}

Introduction: Biochemical changes accompanying intracapsular pathological processes represent potential source of information exploitable in diagnostics, differential diagnostics or monitoring of temporomandibular joint disorders. Miniinvasive intervensions in the temporomandibular joint integrity with synovial fluid acces are performed in dental practice performed for drainage or therapeutic lavage and not for determination of any biochemical parameter. In addition to the invasiveness of the temporomandibular joint puncture, the synovial fluid utilization from this site for diagnostics is complicated by low volume.

Aim of this work is to summarize current knowledge of histology, physiology and pathophysiology of the temporomandibular joint, to evaluate the possibilities of synovial fluid (ST) examination and to test the diagnostic potential of this fluid by means of highly sensitive fluorescence fingerprint analysis.

Keywords: temporomandibular joint - synovial fluid - osteoarthrosis - fluorescence

Čes. Stomat., roč. 118, 2018, č. 3, s. 68-72

\section{ÚVOD}

Vnútorný priestor temporomandibulárneho kíbu (TMK) vypíňa synoviálna tekutina (ST), ultrafiltrát krvnej plazmy produkovaný synovialocytmi. Pre funkciu kíbu zohráva viaceré úlohy: pôsobí ako lubrikant, zabezpečuje fagocytózu cudzorodých častíc a umožňuje výživu kíbovej chrupky [2, 8, 13]. Morfologické zmeny asociované s degeneráciou chrupky pri osteoartróze sú detegovatel'né na RTC až s odstupom dvoch až troch rokov. Laboratórne vyšetrenie punktátu TMK môže prítomnost' degeneratívnych zmien v kíbe odhalit' už krátko po ich nástupe, avšak toto vyšetrenie nie je súčastou dennodennej praxe [10, 21]. Vyšetrenie synoviálnej tekutiny najčastejšie indikuje ortopéd alebo reumatológ pri ochoreniach kolenného kíbu [20].

\section{HISTOLÓGIA A FYZIOLÓGIA TMK}

Výstelku vnútorných častí všetkých synoviálnych kíbov, vrátane TMK, tvoria kíbová chrupka a syno- 


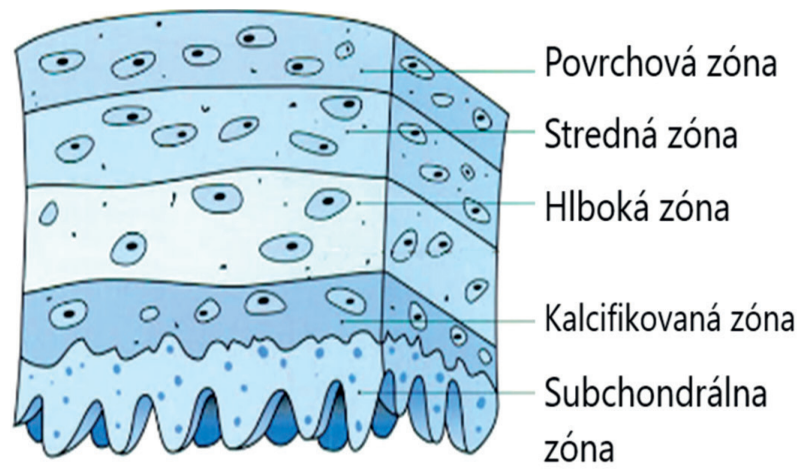

Obr. 1 KÍbová chrupka (upravené podla Miloro, 2004)

viálna membrána. Synoviálna membrána je tenká, hladká, bohato vaskularizovaná a inervovaná, bez epitelu. Tvoria ju málo diferencované synoviálne bunky mezenchýmového pôvodu s fagocytárnou a sekretorickou funkciou. Vd'aka nízkej diferenciácii synovialocytov je synoviálna membrána schopná rýchlo a úplne regenerovat'. Synovialocyty sú miestom syntézy kyseliny hyalurónovej a glykozaminoglykánov, ale aj mnohých cytokínov [4, 13]. Kíbová chrupka je z prevažnej časti tvorená medzibunkovou hmotou (98\%) a chondrocytmi (2\%) uloženými v lakúnach a usporiadanými do troch vrstiev, pričom v každej z nich majú chondrocyty charakteristický tvar a orientáciu (obr. 1). V hlbokej vrstve dochádza ku kalcifikácii chondrocytov a je tu prítomných niekol'ko ciev $[13,16]$.

Chondrocyty sú zodpovedné za reguláciu syntézy intercelulárnej matrix, ktorú tvorí voda, kolagénové vlákna a nefibrózny výplňový materiál. Voda predstavuje $70 \%$ tkaniva chrupky a je viazaná na kolagénové vlákna, ktoré sú tvoréne z 90 \% kolagénom typu II. Podiel'a sa na pružnosti chrupky [5]. Výplňový materiál tvoria rôzne plazmatické proteíny, proteoglykány syntetizované $\mathrm{v}$ Golgiho aparáte chondrocytov, d'alej glukóza, močovina a soli [13].

Chrupka je primárne vyživovaná zo synoviálnej tekutiny [13,16] - čírej, nažltlej, viskóznej, nezrážajúcej sa tekutiny, o ktorej sa zmienil už Hippokrates [2]. Synoviálna tekutina je považovaná za filtrát plazmy a v zdravom TMK je jej objem približne dva mililitre. Za viskozitu zodpovedá kyselina hyalurónová naviazaná na proteíny. Proteóm synoviálnej tekutiny a krvnej plazmy sa odlišujú. Synoviálna tekutina obsahuje proteínov menej, ale s vyšším percentuálnym podielom albumínu a nižším podielom $\alpha 2$-globulínu. Fibrinogén a ostatné proteíny koagulačnej kaskády sa v synoviálnej tekutine nenachádzajú. Koncentrácia lipidov je na rozdiel od plazmy vel'mi nízka. Katióny $\mathrm{Na}^{+}, \mathrm{K}^{+}$a $\mathrm{Ca}^{2+}$ sú v niž- ších koncentráciách a naopak anióny $\mathrm{Cl}^{-}$a $\mathrm{HCO}_{3}$ vo vyššej koncentrácii ako v plazme. Fyziologické pH synoviálnej tekutiny sa pohybuje v rozsahu 7,31-7,64. Na jeho udržiavaní sa podiel'a významným spôsobom pufrovací systém kalciumhyaluronát [5, 9, 13] . Synoviálna tekutina je na bunky chudobná $(0,01$ až $0,2 \times 10^{9} / 1$ ), prevažujú leukocyty (dominantne monocyty, lymfocyty, makrofágy a $<25 \%$ polymorfonukleárov) [6]. Vo vel'mi nízkych koncentráciách sa aj v zdravom TMK môžu detegovat prozápalové cytokíny (IL-1 - interleukín 1, IL-6 - interleukín 6 a TNF- $\alpha$ - tumor nekrotizujúci faktor $\alpha$ ), protizápalové cytokíny (napr. antagonista receptora IL-1), ale aj regulátory apoptózy RANKL (receptor aktivátor NF kappa-B ligand) a ich inhibítory zabezpečujúce homeostázu v zdravom kíbe [19].

\section{PATOGENÉZA POŠKODENIA CHRUPKY}

Podstatou rozvoja osteoartrózy je poškodenie kíbovej chrupky [5]. Proces deštrukcie chrupky je podmienený nerovnováhou medzi degradačnými enzýmami a ich inhibítormi. Spúštačom degenerácie je pokles množstva a agregácie proteoglykánov s následným úbytkom matrix chrupky. Reaktívna stimulácia syntézy medzibunkovej hmoty chondrocytmi je obranným mechanizmom, vd'aka ktorému je chrupka schopná plnit svoju funkciu ešte určitú dobu. S postupujúcou osteoartrózou chondrocyty vyčerpajú svoju reparačnú schopnost', syntéza proteínov extracelulárneho matrixu chrupky klesá a výsledkom je redukcia chrupky [9] a obnaženie subchondrálnej kosti. Mikrotraumy vznikajúce pri zatažovaní kíbu sa hoja novotvorbou kosti, dochádza k hypertrofii synoviálnej membrány, neovaskularizácii rezíduí chrupky a vzniku osteofytov [5]. Ked'že osteoartróza je chronické progredujúce ochorenie, včasnejšia diagnostika a možnost' sledovat' priebeh ochorenia špecifickejšími a citlivejšími metodikami by pre pacientov bola benefitom [10] .

\section{BIOCHEMICKÉ ZMENY}

Biochemické zmeny súvisia predovšetkým s prítomnostou zápalu, vzniknutým oxidačným stresom počas zápalu a reparačnými mechanizmami. Za rovnováhu medzi procesmi riadenými anabolickými a katabolickými cytokínmi môže vzájomná súhra synovialocytov, chondrocytov a leukocytov [13]. V synoviálnej tekutine artrotického kíbu je znížená koncentrácia aj molekulová hmotnost' kyseliny hyalurónovej. Príčinou je okrem fragmentácie aj narušená syntéza kyseliny hyalurónovej synovialocytmi [7]. Na tvorbu molekúl extracelulárnej 
ČESKÁ STOMATOLOGIE ročník 118, 2018, 3 , s. $68-72$

matrix kíbu sú potrebné anabolické cytokíny ako IGF-I (insulin-like growth factor - I) a TCF- $\beta$ (transforming growth factor - beta) podporujúce reparačné mechanizmy pri osteoartróze a redukujúce množstvo receptorov IL-1 na chondrocytoch $[9,13]$. Katabolické cytokíny IL-1, IL-6, TNF- $\alpha$ sú spojené so syntézou proteáz (aspartátová, cysteínová, serínová a matrix metaloproteinázy - MMP) aktívnych pri nízkom a neutrálnom pH. Zvýšené hladiny cytokínov a MMP boli pozorované $u$ pacientov s osteoartrózou, ale aj u pacientov s dislokáciou disku bez repozície [10, 13]. Cytokín IL-1 a stromelyzín (MMP 3) môžu byt detegované už pri skorých štádiách deštrukcie kosti bez pozitívneho RTC nálezu [11]. Regulácia syntézy cytokínov je ovplyvnená aj pohlavným dimorfizmom. V TMK žien boli nájdené funkčné estrogénové receptory a je popísaný antinociceptívny efekt estrogénu a testosterónu počas zápalového procesu [1, 22] .

Aktiváciu cytokínov, neuropeptidov, degradačných enzýmov a metabolitov kyseliny arachidónovej, ktorá vyústuje do degeneratívneho ochorenia kíbu, zvyšujú aj vol'né radikály. V patogenéze osteoartrózy sa významne uplatňuje oxid dusnatý (NO), a to viacerými mechanizmami. V nízkych koncentráciách zvyšuje permeabilitu ciev, zvyšuje uvol'ňovanie TNF, IL-1 a MMP, inhibuje reparačné pochody chrupky a vyvoláva apoptózu. Vo vyšších koncentráciách reaguje s kyslíkovými radikálmi za vzniku cytotoxických látok, napríklad peroxynitritu reagujúceho s tyrozínom za vzniku nitrotyrozínu, ktorého prítomnost' bola pri osteoartróze dokázaná v synoviálnej tekutine. Za fyziologických okolností chrupka produkuje NO len po pôsobení cytokínov, zatial' čo pri osteoartróze prebieha syntéza NO aj spontánne [5, 13].

\section{SÚČASNÉ MOŽNOSTI VYŠETRENIA SYNOVIÁLNEJ TEKUTINY}

Synoviálna tekutina nepatrí medzi rutinne vyšetrované biologické tekutiny. V ortopédii a reumatológii sa najčastejšie vyšetruje synoviálna tekutina z kolenného kíbu [5, 20]. Makroskopicky sa vyhodnocuje farba, zákal a viskozita. Za normálnych okolností je synoviálna tekutina bezfarebná, číra a vysoko viskózna. Viskozita synoviálnej tekutiny je normálna, ak kvapku synoviálnej tekutiny je možné natiahnut na vlákno dlhšie ako tri centimetre. Pri osteoartróze je viskozita znížená. Ďalším orientačným testom na posúdenie polymerizácie kyseliny hyalurónovej je mucínový zrážací test, pri ktorom sa k jednému milimetra synoviálnej tekutiny pridajú $4 \mathrm{ml} 2$ \% kyseliny octovej. Za fyziologických okolností vzniká tuhá formovaná zrazenina vo vyčírenom roz- toku, avšak pri zápalových zmenách vzniká difúzne zakalenie. Ďalšie laboratórne vyšetrenia synoviálnej tekutiny sú biochemické (pH, glukóza, laktát, kyselina močová, celkové proteíny), cytologické (počet leukocytov + diferenciál), mikroskopické (dôkaz kryštálov) a imunologické (vyšetrenie protilátok, autoprotilátok a reumatoidného faktora). $\mathrm{V}$ prípade výrazne zakaleného výpotku sa synoviálna tekutina odosiela na mikrobiologické vyšetrenie $[17,20]$.

$\mathrm{V}$ priebehu posledných dvoch desat'ročí došlo $\mathrm{k}$ vel'kému pokroku $\mathrm{v}$ chápaní etiopatogenézy chronickej bolesti, zápalových a degeneratívnych zmien temporomandibulárneho kíbu. Osteoartróza začína v kíbovej chrupke a pozitívny rádiologický nález má latenciu dva až tri roky $[10,13]$. Analýza synoviálnej tekutiny už v čase nástupu klinických tažkostí (akými sú bolesti TMK, krepitus a hypomobilita TMK) by mohla byt' prínosom pre skorší začiatok správnej liečby. Najnovšie vedecké práce informujú o význame stanovenia koncentrácie cytokínov, najmä IL-1 $\beta$, IL-6, IL-8, IL-11, TNF- $\alpha$ a MMP3, pri hodnotení intenzity denegeratívnych zmien $\mathrm{v}$ čase negatívneho RTC nálezu [21].

\section{FLUORESCENČNÁ ANALÝzA}

V priebehu posledných dvadsiatich rokov došlo $\mathrm{k}$ zintenzívneniu používania fluorescencie $\mathrm{v}$ oblasti biologických vied. Z biochémie a biofyziky sa jej použitie rozšírilo aj do d'alších oblastí a dnes sa využíva v prietokovej cytometrii, biotechnológiách, medicínskej diagnostike, genetickej analýze a d'alších [12] .

Luminiscencia je pojem označujúci emisiu svetla z akejkol'vek látky v excitovanom stave. Je rozdelená na dva typy (fluorescencia a fosforescencia) v závislosti od charakteru excitovaného stavu. Po absorpcii svetla určitej vlnovej dížky elektróny prechádzajú do vzbudeného stavu. Vzbudený singletový elektrón sa spáruje s druhým vol'ným elektrónom, čím sa vracia do základného tvaru a dochádza k emisii fotónov [14].

Fluorofóry sú látky, u ktorých je možné pozorovat' fluorescenciu. Exogénne fluorofóry sú dodané do organizmu s ciel'om dosiahnut fluorescenciu. Ak sú prítomné v organizme, hovoríme o endogénnych fluorofóroch, čím umožňujú autofluorescenciu [18]. Medzi najdôležitejšie endogénne fluorofóry radíme molekuly, ktoré sú mohutne distribuované v bunkách a tkanivách, ako sú proteíny, ktoré obsahujú aromatické aminokyseliny, NADPH, lipopigmenty a flavíny. Autofluorescencia môže narastat' vd'aka štrukturálnym proteínom (najmä kolagén a elastín - najdôležitejšie fluorofóry extracelulárnej matrix). Hlavnou výhodou autofluorescencie je možnost' sledovania natívnych vzoriek $v$ reálnom čase bez biopsie 


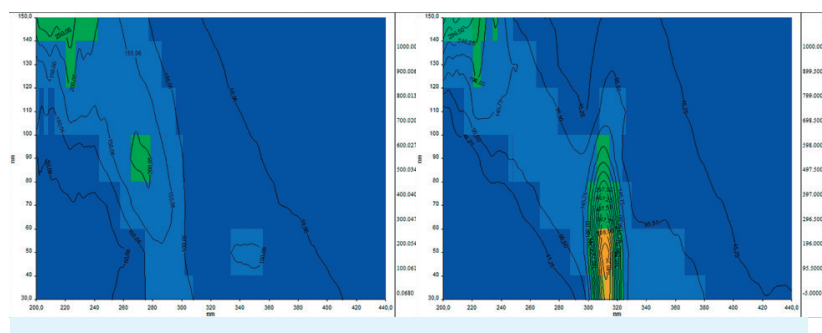

Obr. 2 Porovnanie fluorescenčných fingerprintov pacientov 1 a 2 Os x - excitačná vlnová dlžka v nm; os y - Stokesov posun v nm

a potrebných príprav k histologickému vyšetreniu [15].

\section{MATERIÁL A METODIKA NA PILOTNÉ FLUORESCENČNÉ VYŠETRENIE SYNOVIÁLNEJ TEKUTINY TEMPOROMANDIBULÁRNEHO KĹBU}

Synoviálna tekutina bola odobraná dvom pacientom na I. stomatologickej klinike LF UPJš a UNLP v Košiciach. Pacientovi vo veku 57 rokov bola diagnostikovaná arthrosis articulationis temporomandibularis bilateralis, u pacienta vo veku 18 rokov bola pozorovaná dislocatio disci anterioris bilateralis. U oboch pacientov bola indikovaná artrocentéza s podaním kyseliny hyalurónovej. Odber vzorky synoviálnej tekutiny v objeme $20 \mu \mathrm{l}$ bol uskutočnený po predchádzajúcej aplikácií dvoch mililitrov fyziologického roztoku.

Odber ST bol realizovaný tesne pred samotným výkonom. Spracovanie a fluorescenčná analýza vzoriek prebehla na Ústave lekárskej a klinickej biochémie LF UPJŠ v Košiciach. Vzorky ST boli nariedené deionizovanou vodou v pomere $20 \mu \mathrm{l}$ vzorka ku $480 \mu \mathrm{l}$ deionizované vody. Následne bola uskutočnená fluorescenčná analýza synoviálnej tekutiny s použitím spektrofotometra Perkin Elmer LS 55 (Waltham, Masschusetts, USA). Merané boli synchrónne fluorescenčné matrice pri nasledovných nastaveniach prístroja: rozsah vlnových dížok 200-600 nm, posun emisného monochromátora oproti excitačnému $\Delta \lambda=30 \mathrm{~nm}$, počet skenov 10 , krokovanie $20 \mathrm{~nm}$, rýchlost' skenovania $1200 \mathrm{~nm} / \mathrm{min}$, štrbiny ex/em: 10/10 nm.

\section{VÝSLEDKY}

Z nameraných údajov je zrejmé, že u pacienta č.1 je vo fluorescenčnom fingerprinte prítomné fluorescenčné centrum ex/em 273/363 nm s intenzitou 280 a.u. typické pre proteíny s obsahom tryptofá$\mathrm{nu}$. Na rozdiel od pacienta 1 je u pacienta 2 nižšia intenzita fluorescencie (131 a.u.) v oblasti proteínov s obsahom tryptofánu. Zároveň je na synchrónnej matrici viditel'né výrazné atypické fluorescenčné centrum s maximom pri vlnových dížkach ex/em $312 / 362 \mathrm{~nm}$ (obr. 2, 3).

\section{DISKUSIA}

Jednou z možností vyšetrenia synoviálnej tekutiny je vysoko citlivá fluorescenčná analýza. Predošlé práce skúmajúce fluorescenciu synoviálnej tekutiny získanej z laktového kíbu psov popisujú vyššiu intenzitu fluorescencie typickej pre proteíny u skupiny psov so zápalovo-degeneratívnymi ochoreniami v porovnaní so skupinou zdravých psov [3]. V našom experimente mal pacient 1 bilaterálne artrózu TMK a zároveň jeho fluorescencia v oblasti $273 / 363 \mathrm{~nm}$ bola asi dvojnásobne vyššia ako u pacienta 2 ošetrovaného pre obojstrannú dislokáciu disku bez degeneratívno-zápalových zmien. Naše výsledky z pilotnej štúdie sú teda $\mathrm{v}$ súlade $\mathrm{s}$ porovnávanou štúdiou. Počet vzoriek bol vzhl'adom na náročnost' odberu a jeho invazivitu nízky, a preto ich nemožno štatisticky vyhodnocovat', avšak korelácia s výsledkami autorov Bilská a kol. [3], u ktorých bol experiment vykonaný na väčšom súbore vzoriek (zdravý/s osteoartrózou $\mathrm{N}=29 / 9$ ), nasvedčuje, že vyšetrenie natívnej fluorescencie synoviálnej tekutiny metódou snímania fluorescenčného fingerprintu má určitý diagnostický potenciál, ktorý by mohol byt' v budúcnosti bližšie popísaný.

\section{ZÁVER}

Vyšetrenie synoviálnej tekutiny temporomandibulárneho kíbu nie je bežnou súčastou diagnostiky ochorení TMK, ale potenciál vyšetrenia tohto relatívne málo prebádaného biologického materiálu

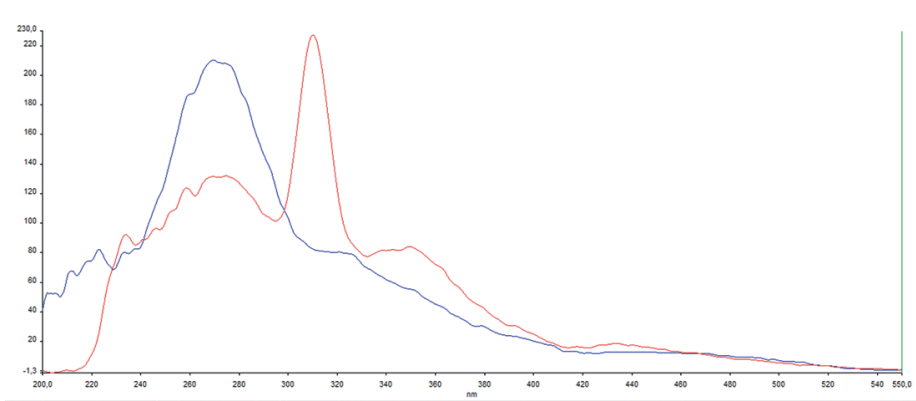

Obr. 3 Porovnanie synchrónnych spektier u oboch pacientov pri Stokesovom posune $90 \mathrm{~nm}$; obrázok demonštruje výrazne rozdielnu fluorescenciu v oblasti proteínov (excitácia 270-280 nm) a atypický pík pri $312 \mathrm{~nm}$

Os x - excitačná vlnová dížka; os y - intenzita fluorescencie; modrá - pacient 1; červená pacient 2 
ČESKÁ STOMATOLOGIE ročník 118 ,

pre včasnú diagnostiku intrakapsulárnych ochorení TMK je vel'ký napriek náročnosti odberu a nízkemu objem odobranej vzorky. Za zvýšenú popularitu fluorescenčných metodík v oblasti biologických vied je zodpovedná ich vysoká citlivost' a jednoduchost' prevedenia. Fluorescenčná analýza vykazuje diagnostický potenciál aj pri malom objeme vzorky. Pilotný experiment ukázal, že fluorescencia synoviálnej tekutiny v oblasti spektra vlnových dížok typického pre proteíny je signifikantne vyššia u pacientov s degeneratívno-zápalovými zmenami oproti kontrole a v prípade, že by sa odberová procedúra optimalizovala, mohla by sa v budúcnosti vykonat na väčšom počte pacientov.

\section{LITERATÚRA}

1. Abubaker, O. A., Lam, D., Benson, K. J.: Oral and maxillofacial surgery secrets. 3. vydanie. Mosby, 2015. 576 s. ISBN: 978-0323-29430-0.

2. Aceves-Avila, F. J., et al.: The first descriptions of terapeutic arthrocentesis: a historical note. In: Rheumatology [online], roč. 42, 2003, č. 1, s.. 180-183. Dostupné na internete: http://rheumatology.oxfordjournals.org/content/42/1/180.full.

3. Bilská, K., Šteffeková, Z., Birková, A., et al.: The use of native fluorescence analysis of synovial fluid in diagnosis of medial compartment disease in medium- and large-breed dogs. J Veterinary Diagnostic Invest., roč. 28, 2016, č. 3, s. 332-337.

4. Čihák, R.: Anatomie 1. 3.vyd. Praha: Grada, 2011. 534 s. ISBN 978-80-247-3817-8.

5. Dungl, P.: Ortopedie. Praha: Grada, 2005. 1280 s. ISBN 80-2470550-8.

6. Faryna, A., Goldenberg, K.: Joint fluid., clinical methods: the history, physical, and laboratory examinations. 3rd edition. Boston: Butterworths, 1990. In: Walker, H. K., Hall, W. D., Hurst, J. W., eds. Chapter 166. Available from: https://www.ncbi.nlm. nih.gov/books/NBK274/.

7. Guarda-Nardini, L., et al.: Intra-articular injection of hyaluronic acid for temporomandibular joint osteoarthritis in elderly patients. Stomatologija, Baltic Dental Maxillofacial. J., roč. 11, 2009, Č. 2, s. 60-65.

8. Hand, A. R., Frank, M. E.: Fundamentals of oral histology and physiology. John Wiley\&Sons Inc, 2014. 296 s. ISBN 978-1-11834291-6.

9. Hulín, I., a kol.: Patofyziológia. 7. vyd. Bratislava: Slovak Academic Press, 2009. 1288 s. ISBN 978-80-8095-043-9.

10. Kostrzewa-Janicka, J., Jurkowski, P., Nędzi-Góra, M., Mierzwińska-Natalska, E.: Inflammatory markers in temporomandibular joint disorders. Central European Journal of Immunology [online]. roč. 37, 2012, č. 3, s. 290-293 [cit. 201607-30]. Dostupné na internete: www.termedia.pl/Reviewpaper-Inflammatory-markers-in-temporomandibular-jointdisorders,10,19473,0,1.html.
11. Kubota, E., et al.: Interleukin 1 beta and stromelysin (MMP3) activity of synovial fluid as possible markers of osteoarthritis in the temporomandibular joint. Journal of Oral and Maxillofacial Surgery [online]., roč. 55, 1997, č. 1, s. 20-27 [cit. 2016-0801]. Dostupné na internete: www.ncbi.nlm.nih.gov/pub$\mathrm{med} / 8994464$

12. Lakowicz, R. J.: Principles of fluorescence spectroscopy. 3. vyd. Baltimore: Springer, 2006. 954 s. ISBN 978-0-387-31278-1.

13. Miloro, M., Ghali, G. E., Larsen, P., Whaite, P.: Peterson's principles of oral and maxillofacial surgery. 2. vyd. Hamilton: BC Decker Inc, 2004. 1500 s. ISBN 1-55009-234-0.

14. Miškovský, P., Uličný, J., Sedlák, M.: Praktikum k experimentálnym metódam biofyziky I: Metódy optickej spektroskopie. Košice: UPJŠ, 1989, 223 s. ISBN 8070970065.

15. Monici, M.: Cell and tissue autofluorescence research and diagnostic applications. Biotechnol. Ann. Rev., roč. 11, 2005, s. 227256.

16. Naujoks, C., et al.: Principles of cartilage tissue engineering in TMJ reconstruction. In: Head\&Face medicine [online]., roč. 4, 2008, č. 3 [cit. 2016-07-27]. Dostupné na internete: https:// head-face-med.biomedcentral.com/articles/10.1186/1746$-160 X-4-3$

17. Olejárová, M.: Revmatologie v kostce. Praha: Triton, 2008. 231 s. ISBN 978-80-7387-115-4.

18. Pierce, C. M., Javier, J. J., Richards-Kortum, R.: Optical contrast agents and imaging systems for detection and diagnosis of cancer. International Journal of Cancer. [online]., roč. 123, 2008, č. 9, s. 1979-1990 [cit. 2017-04-22]. Dostupné na internete: www.ncbi.nlm.nih.gov/pmc/articles/PMC2902964/.

19. Smith, M. D.: The normal synovium. In: The Open Rheumatology Journal [online]. roč. 5, 2011, č. 1, s. 100-106 [cit. 2016-07-27]. Dostupné na internete: www.benthamopen.com/FULLTEXT/ TORJ-5-100

20.Trnavský, K., Rybka, V., a kol.: Syndrom bolestivého kolena. Praha: Galén, 2006, 225 s. ISBN 80-7262-391-5

21. Tvrdý, P.: Stanovení hladiny cytokinů v klobní tekutině jako alternatívní možnost vyšetření vnitřních poruch temporomandibulárního kloubu. Čes. Stomatol., roč. 111, 2011, č. 4, s. 82-88.

22. Torres-Chávez, K. E., Sanfins, J. M., Clemente-Napimoga, J. T., et al.: Effect of gonadal steroid hormones on formalin-induced temporomandibular joint inflammation. Eur. J. Pain., roč. 16, 2012, č. 2, s. 204-216. doi: 10.1016/j.ejpain.2011.06.007. 